\title{
Ratooned fennel relies on osmoregulation and antioxidants to damp seed yield decline with water limitation
}

\author{
Morteza Akbari-Kharaji ${ }^{1} \cdot$ Parviz Ehsanzadeh $^{1}$ (D) $\cdot$ Ali Gholami Zali ${ }^{1} \cdot$ Ehsan Askari ${ }^{1} \cdot$ Ahmad Rajabi-Dehnavi $^{1}$
}

Accepted: 31 January 2020 / Published online: 18 February 2020

(C) INRAE and Springer-Verlag France SAS, part of Springer Nature 2020

\begin{abstract}
Fennel (Foeniculum vulgare Mill.) is a medicinal species which has not been examined as a ratoon crop. Ratooning lessens the production intensity, but the ratooned fennel seed yield and physiological processes may differ with stand age, irrigation regime, and genotype. Eleven fennel genotypes were, thus, subjected to either limited or sufficient water supply for 6 years. For each year, the crop was harvested in early autumn to measure seed yield, yield components, dry mass, and essential oil. Besides, some physiological characteristics relevant to seed yield were studied in certain years. Results indicated a biphasic behavior in seed and essential oil yields of the majority of genotypes with maximum seed yields (ranging from 2514 to $2635 \mathrm{~kg} \mathrm{ha}^{-1}$ in different genotypes) being obtained from the well-watered plants mainly in the 4th year of harvest. Taking the period of 6 years and the two irrigation regimes together, genotypes Yazd, Kashan, and Shiraz showed a better productive performance. Meaningful positive associations were found between the seed yield and such yield components as seeds/plant and certain physiological attributes, i.e., proline and total soluble carbohydrates concentrations, water potential, relative water content, and superoxide dismutase, catalase, and ascorbate peroxidase activities. Maximum seed yields (ranging from 1605 to $1704 \mathrm{~kg} \mathrm{ha}^{-1}$ ) and essential oil yields (ranging from 33.3 to $45.5 \mathrm{~kg} \mathrm{ha}^{-1}$ ) of plants grown under water-limited conditions were found in genotypes that benefited more from osmoregulative and antioxidative roles of proline and the antioxidative enzymes (i.e., Shiraz, Yazd, and Kashan) and, hence, were able to withstand better against water limitation. Considering such physiological capabilities, agronomic performance, and minimum stand age effects, we discovered for the first time that certain fennel genotypes could be proposed as potential resources for growing fennel as an alternative ratooned crop for low production intensity and sustainable cropping in arid climates.
\end{abstract}

Keywords Medicinal plant $\cdot$ Essential oil $\cdot$ Water potential $\cdot$ Antioxidative $\cdot$ Seed yield $\cdot$ Perennial

\section{Introduction}

Ratooning is the cultural practice of cutting crops near their crown after the first harvest of seed or fodder, permitting the crop to grow back for subsequent harvests and, hence, extending production for more than one growing season (Rogé et al. 2016). Thanks to the minimized utilization of agricultural machinery, growing such ratooned crops is thought to lessen the risks of soil degradation and erosion in the already vulnerable arid and semi-arid lands and, in a broader sense, marginal areas occurring typically in the Middle East. In spite of the

Parviz Ehsanzadeh

ehsanzadehp@gmail.com

1 Department of Agronomy and Plant Breeding, College of Agriculture, Isfahan University of Technology, Isfahan 84156-83111, Iran definite advantages of growing certain perennial medicinal species, research data about the potential benefits of perennial medicinal and aromatic plants to the sustainability of the agricultural production systems is rare. In effect, most of the available experimental works have focused on the evaluation of seed and essential oil production of medicinal plants over 1-2 years.

While millions of people rely on collecting and processing of medicinal plants either for health care or income from trade of products, there is a fear that many species in high demand will be endangered due to overharvesting (van Andel et al. 2015). Yet, as a consequence of the growing number of consumers and the wider spectrum of the applications of these compounds, the trade of essential oils is going to expand tremendously worldwide in the foreseeable future (Sangwan et al. 2001). Moreover, medicinal plants are generating much interest in arid and semi-arid parts of the world as alternative sources of crop production in less-productive conditions under 
non-intensive agricultural systems. Continuing a reliance on herbal medicine necessitates conserving these valuable species and hence, in the absence of detailed scientific data, designing appropriate studies on responses of at least commonly traded medicinal plants to environmental factors and agronomic practices. Hence, such necessities have turned the attention of scientists to the medicinal plants (Carrubba and Catalano 2009).

Fennel is an aromatic edible plant from the Umbelliferae (Apiaceae) family and endemic to the Mediterranean conditions, whose mature seeds (Fig. 1a) are used for different purposes since antiquity. Usages in folk medicine, pharmaceutical and cosmetic technology, and production of food preserving compounds in food industries (Diao et al. 2014) are only a few of the main applications of fennel seeds and extracts. Even though it is an herbaceous species that occurs naturally as an annual, it may be cultivated as a perennial crop (Carrubba et al. 2008). An autumn harvest, following retranslocation of nutrients to the crown and bulbous root perennating organs, allows efficient interannual nutrient recycling and spring regrowth (Fig. 1b) in this herbaceous species. Especially interesting is the low-demanding nature and stress-resilient habit of this species as revealed in the previous studies (Gholami Zali and Ehsanzadeh 2018), along
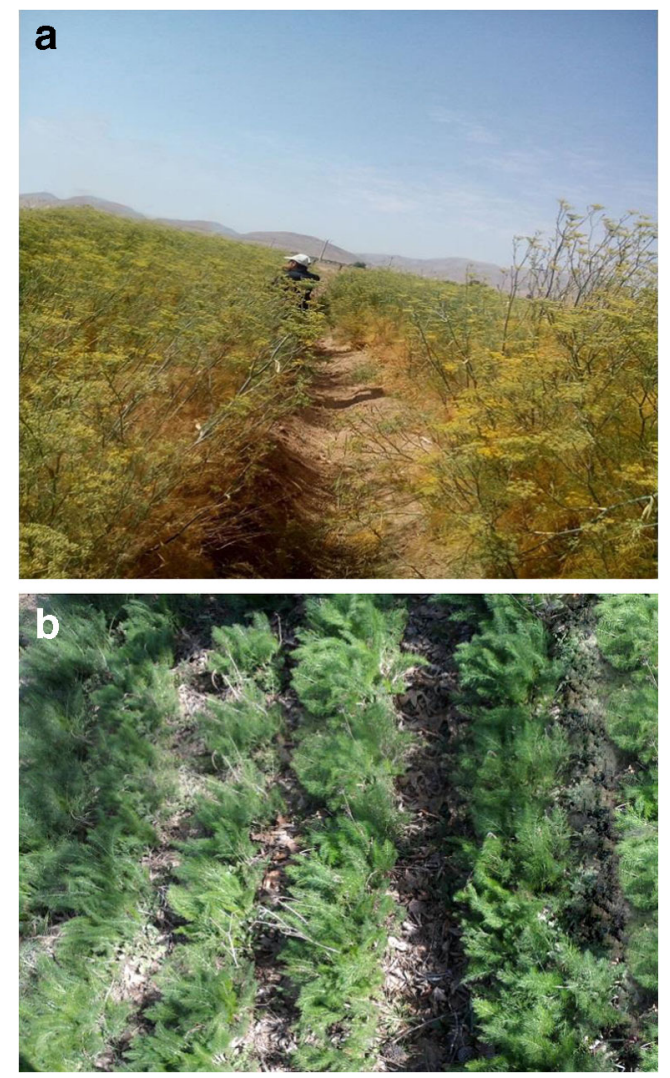

Fig. 1 a Fennel's edible mature seeds are used for different purposes, such as pharmaceutical and cosmetic technology and food industries. b Following an autumn harvest, the over-wintered crown and bulbous root perennating organs of fennel allow a spring regrowth with its different (i.e., compared to ordinary annual crops) production cycle (Carrubba et al. 2008).

Less than $10 \%$ of the world arable lands can be stress-free for plants; they are too often faced with an array of constraints, of which drought may rank first in terms of deteriorating plant growth and, thus, agricultural production (Ashraf and Foolad 2007). The unavoidable aftermaths of global climate change, e.g., raised temperatures, altered seasonal weather patterns, increased frequency, intensity and duration of drought episodes, and aggravated scarcity of irrigation water are going to worsen this problem worldwide, in general, and in arid and semi-arid regions, in particular (Kumar et al. 2017). On the other hand, a notable proportion of the world food demand is fulfilled by agricultural production in regions characterized by an inherent water scarcity, e.g., arid and semi-arid parts of the globe. Yet, secondary salinity (e.g., induced by saline irrigation water) aggravates the adverse effect of drought on agricultural plants and endangers food security in arid and semiarid climates. Plants of less-favorable habitats are expected to have developed adaptation strategies of tolerance to stress factors such as drought. Medicinal plant species occurring in arid and semi-arid regions usually develop adaptive mechanisms for coping with drought stress.

Oxidative stress is known as a secondary phenomenon of environmental stresses imposed on plants, resulting in the generation of the reactive oxygen species (ROS) (Stankovic et al. 2015). Many naturally occurring antioxidant compounds from plant sources are known as reactive oxygen scavengers. Different organs of fennel are potential sources of strong natural antioxidants. Scavenging of ROS in plants exposed to stresses (e.g., drought) is associated with activity of the enzymes involved in antioxidative processes, i.e., superoxide dismutase (SOD), ascorbate peroxidase (APX), and catalase (CAT), the presence of osmoprotectant compounds (such as mannitol, betaine, and proline), and the activity of nonenzymatic antioxidant compounds (such as ascorbic acid, glutathione, thioredoxin, carotenoids, vitamins, and phenolics). While biosynthesis and accumulation of an array of secondary metabolites in plants are considered to be evolutionary response of biochemical pathways to different unfavorable environments such as water deficit, these bioactive compounds may play roles of significance in withstanding stresses (Stankovic et al. 2015). Maintaining internal plant water and turgor potential in a water-limited condition requires an increase in osmotica, normally accomplished by synthesis of metabolically benign solutes, namely organic osmolytes. Accumulation of compatible solutes and osmolytes is known as a means of prolonging plant physiological functions in water-deprived states (LiXin et al. 2009). Though such capabilities have been studied less in the medicinal plants of the fennel type.

To obtain greater essential oil yields and more profitable economics of production of fennel as an alternative cash crop 
under diverse environmental conditions, our research effort has been focused on developing high-yielding cultivars and physiological modulations of essential oil production under environmental stresses (e.g., water-limited conditions). Current cultivation and production of fennel, at least in the Mediterranean climatic conditions, involves sowing this medicinal species as a winter annual in warmer climates and as a spring annual in cooler areas. This necessitates repeated and, hence, intensive cultural practices in each and every year. Since ratooning minimizes cultural practices and labor costs, we aimed at shedding light on the question of suitability of fennel as a ratoon crop under different soil moisture conditions. In order to arrive at a more appropriate answer to this question, interrelations of seed yield, yield components, and some physiological attributes of fennel were also examined.

\section{Materials and methods}

\subsection{Genetic materials, soil preparation, sowing, irrigation, and maintaining the plants}

This 6-year field experiment was carried out at the Lavark Research Farm of Isfahan University of Technology in Najaf Abad $\left(32^{\circ} 32^{\prime} \mathrm{N}, 51^{\circ} 23^{\prime} \mathrm{E}, 1630 \mathrm{~m}\right.$ above mean sea level), Isfahan, Iran, from 2011 to 2017. Irrigation treatment consisted of irrigation after 35-45\% (well-watered) and 75$85 \%$ (water-limited) depletion of available soil water (ASW) and the 11 fennel genotypes were "Urmia," "Hamadan," "Kerman," "Shiraz," "Birjand," "Yazd," "Avicenna," "Kashan," "Mashhad," "Bushehr," and "Isfahan." The soil was a Fine Loam Typical Haplargid with the initial N, P, K, $\mathrm{Zn}$, and $\mathrm{Fe}$ contents of $740.0,25.0,225.0,3.8$, and $9.4 \mathrm{mg} \mathrm{kg}^{-1}$, respectively. The soil that had previously been under wheat was tilled and prepared for seeding (consisting of plowing, double-disk harrowing, leveling, and farrowing) in the winter of 2010. The fennel genotypes were obtained from different geographical regions of Iran (hence, were broadly adapted to a wide range of habitats); the seeds were disinfected by a $5 \%$ sodium-hypochlorite solution, washed by distilled water, germinated in peat moss and grown to 34 leaf stage in plastic trays. Subsequently, the seedlings were transferred to the field in late March 2011. Prior to transferring the seedlings, the plots were irrigated and the seedlings were planted into the irrigated soil. Each plot consisted of five 2-m long farrows spaced $50 \mathrm{~cm}$ apart, with seedlings being planted $20 \mathrm{~cm}$ apart on each ridge. Hence, fennel plants were planted at the target initial population of 100,000 plants $\mathrm{ha}^{-1}$. Preplanting fertilizers were avoided as soil analysis did not identify nutrient deficiencies, except for a urea fertilizer $(46 \% \mathrm{~N})$ at $150 \mathrm{~kg} \mathrm{ha}^{-1}$. Nitrogen fertilizer was applied each year at growth onset (when plants were nearly $40 \mathrm{~cm}$ tall) in late March to early April (with the exception of the establishment year) as side dressing at $150 \mathrm{~kg} \mathrm{ha}^{-1}$ (i.e., urea) before commencing irrigation treatments. The plants were watered two or three times in late winter and early spring each year, then irrigation regimes were applied and continued to approximately $75 \%$ physiological maturity, that is, late September of 2011 (i.e., the establishment year) and early to mid-September of the 2012 to 2017. Plots were kept weed-free over the course of the 6-year study by hoeing. No crop diseases and insects were detected during the years $1-4$ of the experiment, but in the 5 th (2016) and 6th years (2017), application of a Confidor (imidacloprid) insecticide $\left(2.5 \mathrm{ml} \mathrm{L}^{-1}\right)$ deemed necessary for controlling sucking insects such as aphids. Starting from the very first year (i.e., the establishment year), harvests were carried out at the end of each growing season that coincided to mid-September to early October, depending on the year. After fall-winter growth stoppages, the fennels from the previous year regrew, to the extent that a fairly uniform canopy of the stubble crop was achieved around the second half of March each year. While plant height was determined and border plants were not harvested, the outer row in each plot was considered the guard row; plants of a $2-\mathrm{m}^{2}$ area were cut at 7 $10 \mathrm{~cm}$ above the ground level. A synopsis of temperature and precipitation data was obtained from the nearby Najafabad Weather Station (Fig. 2). The irrigation treatments were applied by calculating ASW, readily available soil water, and the volume of irrigation water and an irrigation water use efficiency of $70 \%$ according to Askari and Ehsanzadeh (2015). Irrigations were carried out based on the maximum allowable depletion (MAD) percentage of ASW (i.e., when 35-45\% and $75-85 \%$ of the ASW were depleted from the root zone for the well-watered and water-limited regimes, respectively). A curve of soil moisture release was created and used to determine the depletion of the ASW based on the soil water potential. Equation (1) was used for determining the irrigation water volume $\left(\mathrm{V}_{\text {irrig }}\right)$ required to rise the water content in the root zone to field capacity.

$V_{\text {irrig }}=\frac{\mathrm{ASW} \times f}{E_{a}}$

In this equation, $f$ is the fraction of ASW (35-45\% and 75$85 \%$ ) that can be depleted from the root zone, and $E_{a}$ is the irrigation efficiency (\%). Irrigation efficiency was assumed to be 70\% (Askari and Ehsanzadeh 2015). A synopsis of volume of irrigation water (i.e., applied with a pipe and measured by a flow meter) is as follows: Averaged over the 6 years, wellwatered plots received 16.5 irrigations and the inadequately watered plots received 6.5 irrigations per year. In each irrigation event, the well-watered and inadequately watered plots received an amount of 50.6 and $101.3 \mathrm{~L} \mathrm{~m}^{-2}$ water, respectively, as these amounts were calculated to be necessary for increasing the root zone soil water content to the field 
Fig. 2 A synopsis of mean monthly temperatures and total precipitations over the course of the 6-year long experiment. Data have been obtained from Najafabad Weather Station $\left(32^{\circ}\right.$ $\left.63^{\prime} \mathrm{N}, 51^{\circ} 37^{\prime} \mathrm{E}\right)$, Najafabad, Isfahan, central Iran
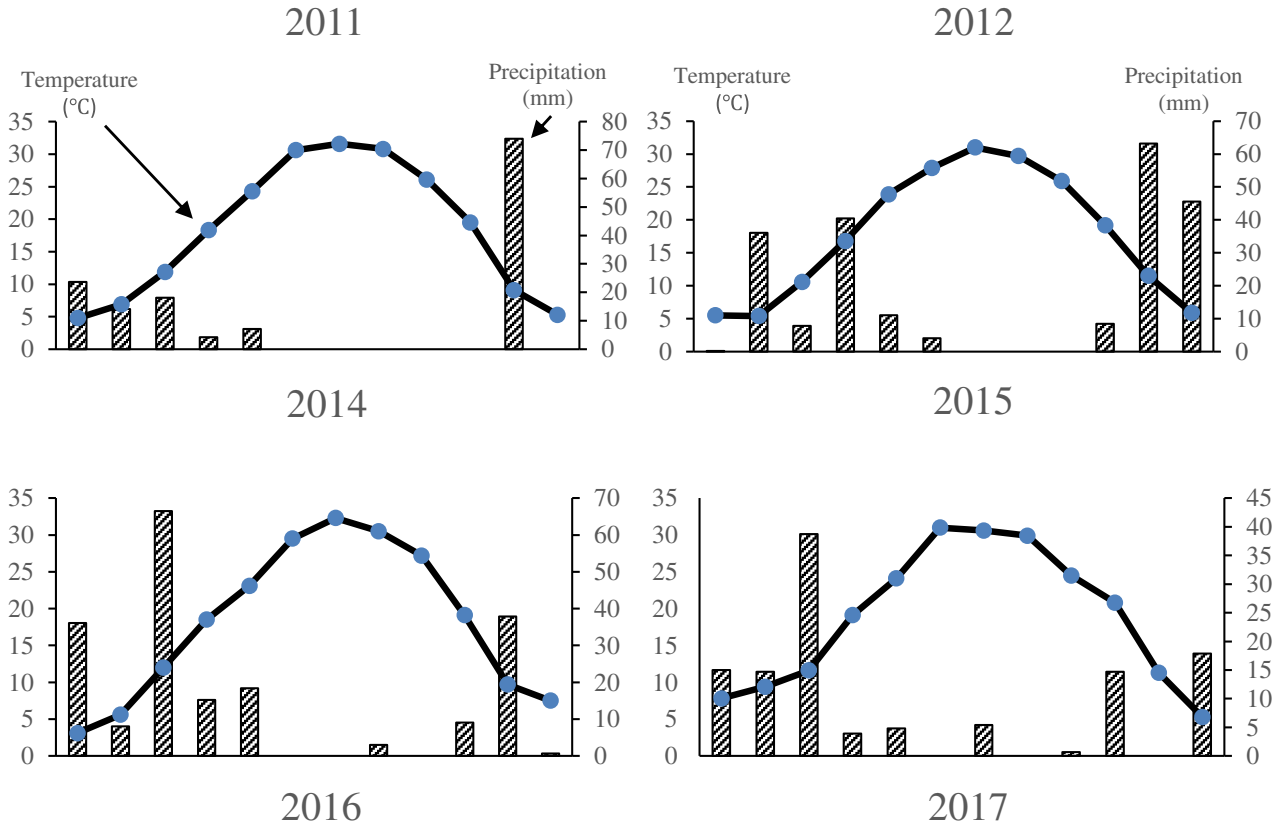

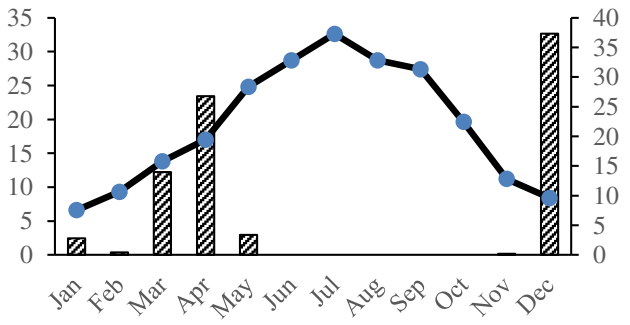

Time period

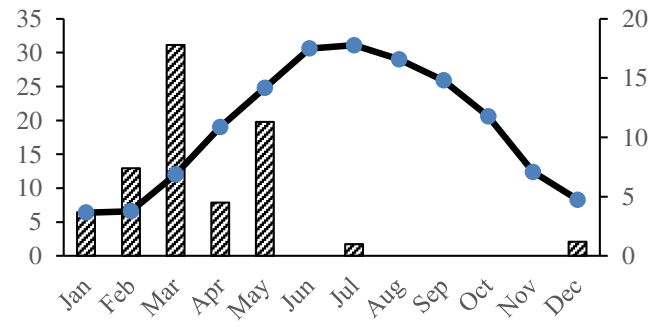

Time period capacity. Total volume of irrigation water given to the wellwatered and inadequately watered plots in each year was 836 and $659 \mathrm{~L} \mathrm{~m}^{-2}$, respectively; hence, the inadequately watered plants received nearly $21 \%$ less water, compared with the well-watered plants.

\subsection{Yield, yield components, and essential oil measurements}

Being an indeterminate crop species, the fennel plants were considered mature when $70-80 \%$ of the leaves and umbels turned yellowish. Seeds/plant and 1000-seed weights were determined using five plants from the 2 nd row of each experimental unit (i.e., plot) at physiological maturity. At around physiological maturity, the plants from the central $2-\mathrm{m}^{2}$ portion in each plot were harvested, air dried for at least 7 days, and seed yield was determined for the 6 years of harvest. Above-ground dry mass (DM) was determined by drying harvested whole plant samples at $72{ }^{\circ} \mathrm{C}$ for $72 \mathrm{~h}$ in the aforementioned years. The harvest index was determined as the ratio of seed weight to DM. Moreover, a 20-g sample of seeds of each plot was grinded to a powder and $200 \mathrm{~mL}$ of deionized water was used for carrying out the hydrodistillation process on the essential oil at $100{ }^{\circ} \mathrm{C}$ (Askari and Ehsanzadeh 2015). The essential oil phase was separated, dried over anhydrous sodium sulfate, and essential oil concentration and yield were expressed as percent and kilograms per hectare, respectively.

\subsection{Leaf water relations and osmolytes measurements}

As the main purpose of this study was to elucidate agronomic attributes of fennel as a ratooned crop, assessment of the physiological attributes was limited to the final year of the study (i.e., the 6th year). At the 50-70\% flowering stage, leaf water potential, relative water content (RWC), proline, and total soluble carbohydrate (TSC) concentrations of plants in each experimental unit were measured in early June of the 6th year (i.e., 2017). Mid-day water potential was determined as described in Askari and Ehsanzadeh (2015) using a portable pressure chamber instrument (PMS Model 600, USA). The mean of two measurements was calculated for each plot. RWC was measured on leaf sections by measuring turgid, fresh, and dry masses according to the procedure explained in the aforementioned study. Free proline content of the leaves was measured using $200 \mathrm{mg}$ of fresh mature leaves that had been crushed in sulphosalicylic acid and added into a 
ninhydrin reagent and assessed according to spectrophotometric absorbance at $520 \mathrm{~nm}$ (Hitachi U1800, Japan), as detailed in Askari and Ehsanzadeh (2015). Leaf TSC was measured using $500 \mathrm{mg}$ of homogenized samples of dried leaves that had been ethanol-extracted and mixed with anthrone and subjected to spectrophotometric measurements at $625 \mathrm{~nm}$ according to the details given in the latter study.

\subsection{Antioxidative enzymes activity and carotenoids measurements}

The concentration of carotenoids in fresh leaves was measured using $500 \mathrm{mg}$ of fresh leaf tissue that had been taken at $70 \%$ flowering of the 1 st and 2 nd years, crushed in a $80 \%$ acetone solution, extracted and subjected to the spectrophotometer for measuring absorbencies according to the details given by Askari and Ehsanzadeh (2015).

In order to measure antioxidant enzymes activities, $500 \mathrm{mg}$ of leaf samples that had been obtained around the 50-70\% flowering stage were homogenized in an extraction buffer, centrifuged at $15,000 \mathrm{rpm}$ for $20 \mathrm{~min}$ at $4{ }^{\circ} \mathrm{C}$ and enzyme activities were expressed according to the measured total protein content of the samples. APX activity was measured spectrophotometrically by a decrease in the absorbance at $265 \mathrm{~nm}$ according to method described by Gholami Zali and Ehsanzadeh (2018). CAT activity was measured by measuring consumption of $\mathrm{H}_{2} \mathrm{O}_{2}$ using absorption by spectrophotometer at $240 \mathrm{~nm}$ according to the details given in the aforementioned study. The activity of SOD was assayed by measuring ability to inhibit photoreduction of nitro blue tetrazolium (NBT) using the procedure described by Askari and Ehsanzadeh (2015).

\subsection{Statistical analysis}

The experimental design was a split-plot randomized complete block with three replications. Over the course of the 6 years of this study, a plot was considered to be the experimental unit and all statistical analyses and calculations were carried out on the plot mean. A mixed model repeated-measures ANOVA was employed to evaluate differences in yield and yield components between genotypes across the entire study period (i.e., 6 years of harvest). Genotype and irrigation were treated as fixed categorical variables, and year was specified as a repeated-measure term with a plot as the experimental unit. Albeit, leaf water relations, osmolytes concentration, and antioxidative activities were measured only in certain years, these data were subjected to a simple analysis of variances. Tukey's Honestly Significant Difference (HSD's) procedure was employed to conduct mean comparisons.

\section{Results and discussion}

\subsection{Agronomic and seed essential oil attributes over the course of 6 years}

The two levels of the irrigation regime (with the exception of the harvest index), the 11 fennel genotypes, and the 6 years of harvest were found to bear significant differences in terms of seed yield, DM, harvest index, 1000-seeds weight, seeds/ plant, plant height, essential oil concentration, and essential oil yield (Table 1). Furthermore, genotype $\times$ irrigation, year $\times$ irrigation, year $\times$ genotype, and genotype $\times$ irrigation $\times$ year interaction effects were found to be significant for all of the aforementioned traits, except for the 1000-seed weight, where the genotype $\times$ irrigation interaction was not found statistically significant and for the plant DM, where year $\times$ irrigation interaction did not appear to be statistically significant (Table 1). Hence, due to the significant effects found with the mentioned interactions, mean comparisons will be restricted to the second order interactions hereafter (i.e., genotype $\times$ irrigation $\times$ year), unless otherwise emphasized.

\subsubsection{Seed yield, yield components, and plant dry mass}

The majority of the genotypes tended to produce a greater seed yield either in the 2nd, 4th, or 5th years of harvest under the well-watered condition. Albeit, the inadequately watered fennel plants for the majority of genotypes indicated greater seed yields in the 4th year and in a lesser extent in the 3rd and 5 th years of harvest (Table 1). With the exception of a few genotypes that tended to produce a greater seeds/plant in the 2nd year, the remaining genotypes appeared to produce the greatest seeds/plant in the 4 th and 5 th years of harvest both in the presence and absence of water limitation. The greater seed yields of certain genotypes, exemplified by Kashan, Yazd, and Shiraz, were accompanied by greater seeds/plant of these genotypes in most years. Meanwhile, well-watered and inadequately watered 2- and 3-year-old fennel plants produced the greatest 1000 -seed weight; albeit there were a few exceptions, where 1- and 6-year-old plants produced the greatest 1000seed weight. The greatest plant height and, hence, DM (Table 2) of well-watered and inadequately watered plants for most of the genotypes were found in the 5 th and 4 th, and in a lesser extent 3 rd years of harvest.

At present, no long-term continuous yield study is available in the peer-reviewed literature, making an accurate assessment of the yield trend of fennel much difficult. The main source of economic value associated with using fennel as a medicinal crop is its seeds, from which the maximum amount of essential oil can be extracted (Gholami Zali and Ehsanzadeh 2018). The majority of fennel genotypes showed a similar productivity trend characterized by two seed-yielding phases: an increasing phase from the 1 st to the 4 th year and a decreasing 
Table 1 Means of interactions of genotype $\times$ irrigation regime $\times$ year and a synopsis of analysis of variances

\begin{tabular}{|c|c|c|c|c|c|c|c|c|c|c|c|c|c|c|c|}
\hline \multirow[t]{2}{*}{ Fennel genotype } & \multirow[t]{2}{*}{ Irrigation regime } & \multicolumn{6}{|c|}{ Seed yield $\left(\mathrm{kg} \mathrm{ha}^{-1}\right)$} & \multicolumn{8}{|c|}{ Seeds/plant } \\
\hline & & Year 1 & Year 2 & Year 3 & Year 4 & Year 5 & Year 6 & Year 1 & Year 2 & Year 3 & Year 4 & Year 5 & & Year 6 & \\
\hline \multirow[t]{2}{*}{ Urmia } & W-watered & 1343 & 1858 & 1199 & 1725 & 1596 & 1477 & 3850 & 5167 & 3238 & 5346 & 7038 & & 5153 & \\
\hline & Water-L & 459 & 683 & 1080 & 1156 & 885 & 269 & 1636 & 2380 & 3286 & 6409 & 4802 & & 949 & \\
\hline \multirow[t]{2}{*}{ Hamadan } & W-watered & 1168 & 1608 & 1478 & 1068 & 1556 & 1215 & 3436 & 4443 & 3962 & 3955 & 7199 & & 3860 & \\
\hline & Water-L & 291 & 443 & 655 & 616 & 591 & 161 & 1236 & 1801 & 1880 & 2876 & 3285 & & 580 & \\
\hline \multirow[t]{2}{*}{ Kerman } & $\mathrm{W}$-watered & 543 & 781 & 825 & 2214 & 1585 & 1486 & 2017 & 2760 & 2477 & 7938 & 7492 & & 5654 & \\
\hline & Water-L & 336 & 488 & 601 & 1370 & 889 & 249 & 1573 & 2062 & 1964 & 7876 & 5217 & & 1179 & \\
\hline \multirow[t]{2}{*}{ Shiraz } & W-watered & 1460 & 1874 & 815 & 1861 & 1811 & 1315 & 4607 & 5512 & 2221 & 7369 & 9137 & & 4686 & \\
\hline & Water-L & 776 & 1078 & 713 & 1206 & 901 & 716 & 2921 & 3880 & 2163 & 5676 & 4971 & & 2781 & \\
\hline \multirow[t]{2}{*}{ Birjand } & W-watered & 1120 & 1661 & 2010 & 2247 & 1920 & 1374 & 3509 & 4966 & 5668 & 7409 & 8002 & & 4804 & \\
\hline & Water-L & 321 & 459 & 579 & 904 & 791 & 483 & 1418 & 1910 & 1887 & 3781 & 3984 & & 1832 & \\
\hline \multirow[t]{2}{*}{ Yazd } & $\mathrm{W}$-watered & 1080 & 1429 & 2478 & 2007 & 2177 & 1686 & 3205 & 4269 & 7100 & 7145 & 8033 & & 5785 & \\
\hline & Water-L & 748 & 1079 & 753 & 1605 & 542 & 616 & 2690 & 3855 & 2442 & 8676 & 2874 & & 2272 & \\
\hline \multirow[t]{2}{*}{ Avicenna } & W-watered & 1539 & 2203 & 1175 & 2397 & 2445 & 1289 & 4683 & 6130 & 2965 & 8080 & 10,896 & & 4002 & \\
\hline & Water-L & 299 & 621 & 642 & 1113 & 899 & 499 & 1263 & 2425 & 1772 & 4796 & 4029 & & 1836 & \\
\hline \multirow[t]{2}{*}{ Kashan } & $\mathrm{W}$-watered & 1309 & 1679 & 2291 & 2635 & 2342 & 1563 & 3967 & 4885 & 5616 & 9512 & 10,361 & & 5845 & \\
\hline & Water-L & 529 & 686 & 1089 & 1704 & 623 & 489 & 2037 & 2535 & 2824 & 8268 & 2924 & & 2136 & \\
\hline Mashhad & $\mathrm{W}$-watered & 1043 & 1650 & 1199 & 2514 & 1205 & 1026 & 2627 & 4241 & 3132 & 8891 & 4193 & & 3393 & \\
\hline & Water-L & 461 & 775 & 713 & 1028 & 800 & 174 & 1474 & 2581 & 2008 & 4097 & 4021 & & 662 & \\
\hline Isfahan & W-watered & 1526 & 2110 & 1723 & 1865 & 3319 & 1755 & 4355 & 5556 & 4107 & 5962 & 13,488 & & 6328 & \\
\hline & Water-L & 490 & 688 & 913 & 762 & 856 & 278 & 1846 & 2457 & 2804 & 3606 & 3944 & & 1138 & \\
\hline Bushehr & W-watered & 1213 & 1881 & 1154 & 1132 & 1842 & 1028 & 3338 & 4990 & 3394 & 4067 & 6992 & & 3917 & \\
\hline & Water-L & 413 & 708 & 734 & 867 & 763 & 481 & 1522 & 2471 & 2346 & 4213 & 3580 & & 1816 & \\
\hline Tukey's HSD ${ }_{5 \%}$ & & 123 & & & & & & 529 & & & & & & & \\
\hline & & $1000-\mathrm{se}$ & eds weig & ht $(g)$ & & & & Plant height & $(\mathrm{cm})$ & & & & & & \\
\hline Urmia & $\mathrm{W}$-watered & 3.50 & 3.60 & 3.71 & 3.20 & 2.27 & 2.84 & 93 & 100 & 154 & 177 & 191 & & 153 & \\
\hline & Water-L & 2.80 & 2.87 & 3.30 & 1.83 & 1.90 & 2.84 & 80 & 77 & 137 & 139 & 160 & & 112 & \\
\hline Hamadan & W-watered & 3.40 & 3.63 & 3.73 & 2.70 & 2.20 & 3.14 & 93 & 138 & 176 & 172 & 176 & & 141 & \\
\hline & Water-L & 2.37 & 2.47 & 3.50 & 2.17 & 1.83 & 2.78 & 87 & 30 & 137 & 126 & 135 & & 108 & \\
\hline Kerman & W-watered & 2.70 & 2.87 & 3.33 & 2.77 & 2.10 & 2.65 & 65 & 85 & 172 & 179 & 176 & & 136 & \\
\hline & Water-L & 2.17 & 2.37 & 3.07 & 1.83 & 1.70 & 2.20 & 57 & 55 & 147 & 143 & 157 & & 109 & \\
\hline Shiraz & W-watered & 3.17 & 3.40 & 3.68 & 2.53 & 2.00 & 2.82 & 95 & 125 & 186 & 193 & 183 & & 135 & \\
\hline & Water-L & 2.67 & 2.77 & 3.32 & 2.13 & 1.80 & 2.60 & 82 & 85 & 138 & 127 & 145 & & 119 & \\
\hline Birjand & W-watered & 3.20 & 3.37 & 3.55 & 3.07 & 2.53 & 2.81 & 93 & 123 & 175 & 187 & 177 & & 139 & \\
\hline & Water-L & 2.27 & 2.40 & 3.07 & 2.40 & 1.97 & 2.65 & 67 & 25 & 152 & 140 & 150 & & 117 & \\
\hline Yazd & $\mathrm{W}$-watered & 3.37 & 3.33 & 3.50 & 2.80 & 2.70 & 2.92 & 93 & 92 & 173 & 162 & 178 & & 132 & \\
\hline & Water-L & 2.80 & 2.80 & 3.10 & 1.83 & 1.90 & 2.72 & 68 & 57 & 121 & 111 & 118 & & 112 & \\
\hline Avicenna & W-watered & 3.30 & 3.60 & 3.97 & 3.10 & 2.27 & 3.22 & 110 & 143 & 186 & 185 & 186 & & 150 & \\
\hline & Water-L & 2.37 & 2.57 & 3.63 & 2.30 & 2.23 & 2.72 & 87 & 53 & 138 & 141 & 142 & & 121 & \\
\hline Kashan & W-watered & 3.30 & 3.43 & 4.08 & 2.77 & 2.27 & 2.71 & 88 & 115 & 169 & 156 & 183 & & 121 & \\
\hline & Water-L & 2.60 & 2.70 & 3.87 & 2.10 & 2.13 & 2.29 & 78 & 78 & 132 & 126 & 141 & & 121 & \\
\hline Mashhad & W-watered & 3.97 & 3.90 & 3.83 & 2.83 & 2.87 & 3.01 & 87 & 115 & 172 & 181 & 184 & & 154 & \\
\hline & Water-L & 3.13 & 3.00 & 3.57 & 2.47 & 2.00 & 2.64 & 80 & 60 & 121 & 107 & 127 & & 124 & \\
\hline Isfahan & W-watered & 3.50 & 3.80 & 4.20 & 3.10 & 2.50 & 2.77 & 90 & 145 & 174 & 167 & 182 & & 159 & \\
\hline & Water-L & 2.67 & 2.80 & 3.33 & 2.13 & 2.20 & 2.44 & 82 & 65 & 137 & 135 & 156 & & 105 & \\
\hline Bushehr & W-watered & 3.63 & 3.77 & 3.40 & 2.77 & 2.67 & 2.67 & 80 & 127 & 168 & 159 & 184 & & 140 & \\
\hline & Water-L & 2.73 & 2.87 & 3.13 & 2.10 & 2.17 & 2.64 & 70 & 60 & 123 & 114 & 131 & & 109 & \\
\hline Tukey's HSD $5 \%$ & & 0.11 & & & & & & 12.75 & & & & & & & \\
\hline & & & A sync & psis of & alysis of & variances & & & & & & & & & \\
\hline & Seeds/plant & $1000-\mathrm{S}$ & $\mathrm{H}$ & DM & SY HI & $\mathrm{EOC}$ & EOY & Carotenoids & CAT & APX & SOD & Proline & TSC & RWC & WP \\
\hline Irrigation (I) & $* *$ & $* *$ & $* *$ & $* *$ & ** ns & $* *$ & $* *$ & $* *$ & $* *$ & $* *$ & $* *$ & $* *$ & $* *$ & $* *$ & $* *$ \\
\hline Genotype (G) & $* *$ & $* *$ & $* *$ & $* *$ & $* * \quad * *$ & $* *$ & $* *$ & $* *$ & $* *$ & $* *$ & $* *$ & $* *$ & $* *$ & $* *$ & $* *$ \\
\hline Year (Y) & $* *$ & $* *$ & $* *$ & $* *$ & $* * \quad * *$ & $* *$ & $* *$ & & & & & & & & \\
\hline $\mathrm{G} \times \mathrm{I}$ & $* *$ & ns & $* *$ & $* *$ & $* * \quad * *$ & $* *$ & $* *$ & $* *$ & $* *$ & $* *$ & $* *$ & $* *$ & ns & ns & $* *$ \\
\hline $\mathrm{Y} \times \mathrm{I}$ & $* *$ & $* *$ & $* *$ & ns & $* * \quad * *$ & $* *$ & $* *$ & & & & & & & & \\
\hline $\mathrm{Y} \times \mathrm{G}$ & $* *$ & $* *$ & $* *$ & $* *$ & $* * \quad * *$ & $* *$ & $* *$ & & & & & & & & \\
\hline $\mathrm{Y} \times \mathrm{I} \times \mathrm{G}$ & $* *$ & $* *$ & $* *$ & $* *$ & $* * \quad * *$ & $* *$ & $* *$ & & & & & & & & \\
\hline
\end{tabular}

For each trait means with differences greater than Tukey's HSD value are not significantly different at 0.05 level. ***, significant at $p \leq 0.01 ; n s$, nonsignificant at $p \leq 0.05$; W-watered, well-watered; Water-L, water-limited; $1000-S, 1000$ seeds weight; $H$, plant height; $D M$, plant above-ground dry mass; $S Y$, seed yield; $H I$, harvest index; $E O C$, essential oil concentration; $E O Y$, essential oil yield; $C A T$, catalase; $A P X$, ascorbate peroxidase; $S O D$, superoxide dismutase; TSC, total soluble carbohydrates; $R W C$, relative water content; $W P$, water potential

phase related to the 5 th and 6 th years of growth (Table 1 ). Evidently, seed yields of the majority of the examined genotypes were decreased with stand ages beyond the 4th year. However, this decline was proportionately smaller or 
occurred after the 5 th year in certain genotypes, suggesting a weaker effect of stand age on these genotypes. Overall, the greatest fennel seed yield under well-watered and inadequately watered conditions was obtained from genotypes that were less affected by stand age (i.e., Yazd followed by Kashan, Shiraz, and Isfahan). Precipitations in April-May, when a closed crop canopy had almost been attained, were greater in the 5th and 6th years of harvest, compared with the remaining years. This may account for a tendency to greater plant height, $\mathrm{DM}$, and hence seed yield in the 5 th year for a number of the genotypes. However, since such tendency was not greater in the inadequately watered plants, compared with the wellwatered plants, this proposition was ruled out. Both biphasic pattern of the seed yield and its decline with stand age are generally observed in perennial herbaceous crop species, e.g., Miscanthus $\times$ giganteus and Panicum virgatum (Arundale et al. 2014) and Arundo donax (Angelinia et al. 2009). Among the studied fennel seed yield components, 1000-seed weight and seeds/plant were the least and the most variable attributes, respectively, across irrigation regimes and years (Table 1). Since the greatest seed yields were observed in genotypes with the greatest seeds/plant, it is reasonable to surmise that seeds/plant (unlike 1000-seed weight) was the main contributor to the variations revealed in the seed yield of fennel. This finding conforms to the notion that seed yield of crop plants is mainly tuned by the number of seeds, rather than the individual seed weight (Gholami Zali and Ehsanzadeh 2018). A negative correlation between kernel number per wheat spike and kernel size has been emphasized (Würschum et al. 2018). Furthermore, among all yield components of common bean, seed size (and hence 1000-seed weight) indicated the smallest modifications across different years and locations when plants were grown under drought condition (Assefa et al. 2015). We did not attempt to measure photosynthesis, but a supposedly maintained photosynthesis might have helped fennel to yield higher seeds/plant through lowering flower infertility. Our data share commonalities with those of Carrubba et al. (2008), who reported DM (Table 2) and seed yields of biennial fennel to be around 7000 and $500 \mathrm{~kg} \mathrm{ha}^{-1}$, respectively. Moreover, our findings agree to those of Özel et al. (2019), who reported the maximum seed yield of a fennel genotype to range from 1580 to $1785 \mathrm{~kg} \mathrm{ha}^{-1}$ over the course of two consecutive years. This report has confirmed that fennel seed yield may, also, be affected by plant population density. Even though fennel genotypes in our study were initially established in a given plant population density (i.e., 10 plants $\mathrm{m}^{-2}$ ), differential age-associated modifications in the seed yield of the genotypes might be attributed to changes in population densities during the 6-year study period. The proposed age effects might have soared in the aftermath of the water limitation, leading to substantial decreases in the seed yield of several fennel genotypes in the 5 th and 6th years of harvest. Another shared feature of our results and those of Carrubba et al. (2008) is plant height, where they reported that fennel plant height ranged from around 130 to $150 \mathrm{~cm}$. Drought-induced decreases in growth attributes and plant DM, along with increases in essential oil concentration have been reported for a number of other medicinal plants, including Salvia officinalis (Bettaieb et al. 2009) and Origanum vulgare (Azizi et al. 2009). Moreover, significant decreases in seed yield and yield components of Carum carvi under drought conditions have been noted (Laribi et al. 2009).

\subsubsection{Harvest index and seed essential oil}

Except for a few cases where well-watered plants indicated greater harvest indices in the 6th year, the majority of the genotypes under the water-limited and well-watered conditions indicated the highest harvest indices in the 2nd and to a lesser extent 1st years of harvest (Table 1). While Kashan, Yazd, Shiraz, and Isfahan out-numbered the remaining genotypes under water-limited conditions in terms of the harvest index in several years, genotypes Urmia, Isfahan, and Hamadan indicated greater harvest indices under wellwatered conditions (Table 2).

The harvest index, as a measure of plant photoassimilates partitioning, is a reflection of the fraction of the total DM allocated to the seed and maintaining a high harvest index has been proposed as a suitable strategy for improving crop yield under water-limited conditions. In the present study the higher-yielding fennel genotypes (i.e., Yazd, Kashan, and Shiraz) out-numbered the remaining genotypes in terms of the harvest index at least when grown under water-limited conditions (Table 2). In agreement with our findings, highyielding red common bean genotypes have showed greater harvest index values under drought conditions, leading to a consistent positive correlation between seed yield and harvest index in the presence of stress (Assefa et al. 2015). Given the fact that many medicinal species, including fennel (in contrast to most cultivated crops), have not been submitted to a long lasting genetic improvement process (Carrubba and Militello 2013), the finding that all of the examined genotypes featured a low harvest index across all years and the two irrigation regimes (Table 2) did not come as a surprise. A tendency towards harvest index stability has been confirmed for different crop species, ranging from cereals such as maize (Echarte and Andrade 2003) and barley (Ingvordsen et al. 2015) to legumes such as common bean (Assefa et al. 2015). However, since excessive vegetative regrowth has been emphasized as one of the drawbacks of the ratooning in the literature (Rogé et al. 2016), the tendency of the fennel genotypes to decreasing harvest indices with the harvest year (i.e., stand age) was not far from our expectation.

The tendency to a greater seed essential oil concentration in the 5th and 6th years of harvest was seen in the inadequately 
Table 2 Means of interactions of genotype $\times$ irrigation regime $\times$ year for seed yield, harvest index, seed essential oil concentration, and essential oil yield of fennel

\begin{tabular}{|c|c|c|c|c|c|c|c|c|c|c|c|c|c|}
\hline \multirow[t]{2}{*}{ Fennel genotype } & \multirow[t]{2}{*}{ Irrigation regime } & \multicolumn{6}{|c|}{ Plant above-ground dry mass (ton $\mathrm{ha}^{-1}$ ) } & \multicolumn{6}{|c|}{ Harvest index $(\%)$} \\
\hline & & Year 1 & Year 2 & Year 3 & Year 4 & Year 5 & Year 6 & Year 1 & Year 2 & Year 3 & Year 4 & Year 5 & Year 6 \\
\hline \multirow[t]{2}{*}{ Urmia } & W-watered & 5.37 & 8.27 & 17.97 & 17.33 & 20.04 & 9.33 & 25.0 & 22.7 & 6.68 & 10.5 & 8.18 & 16.2 \\
\hline & Water-L & 2.03 & 2.31 & 17.00 & 12.95 & 17.80 & 2.70 & 22.9 & 29.4 & 6.37 & 8.94 & 5.01 & 9.55 \\
\hline \multirow[t]{2}{*}{ Hamadan } & $\mathrm{W}$-watered & 5.10 & 6.43 & 14.23 & 14.10 & 17.12 & 7.78 & 23.2 & 25.6 & 10.4 & 8.02 & 9.27 & 16.1 \\
\hline & Water-L & 1.65 & 2.34 & 13.28 & 10.37 & 14.35 & 1.44 & 17.8 & 18.9 & 4.93 & 6.04 & 4.01 & 11.8 \\
\hline \multirow[t]{2}{*}{ Kerman } & W-watered & 4.88 & 4.93 & 15.77 & 17.87 & 21.12 & 9.19 & 10.9 & 15.7 & 5.24 & 12.5 & 7.57 & 15.9 \\
\hline & Water-L & 3.08 & 2.71 & 7.67 & 20.80 & 16.35 & 4.55 & 11.2 & 18.3 & 7.84 & 8.16 & 5.43 & 5.16 \\
\hline \multirow[t]{2}{*}{ Shiraz } & $\mathrm{W}$-watered & 6.58 & 9.57 & 18.96 & 21.21 & 22.23 & 9.09 & 22.6 & 19.9 & 4.30 & 8.84 & 8.22 & 14.6 \\
\hline & Water-L & 2.46 & 5.04 & 9.27 & 11.07 & 16.61 & 5.64 & 31.0 & 21.0 & 7.69 & 11.4 & 5.78 & 14.0 \\
\hline \multirow[t]{2}{*}{ Birjand } & $\mathrm{W}$-watered & 6.14 & 7.99 & 12.81 & 16.28 & 18.05 & 7.93 & 18.9 & 20.7 & 15.7 & 14.1 & 10.7 & 16.9 \\
\hline & Water-L & 1.61 & 2.40 & 11.69 & 11.00 & 11.73 & 3.25 & 20.2 & 19.2 & 4.95 & 8.63 & 6.73 & 15.0 \\
\hline \multirow[t]{2}{*}{ Yazd } & W-watered & 5.17 & 7.37 & 26.41 & 14.88 & 20.60 & 7.31 & 21.9 & 19.5 & 9.39 & 13.5 & 10.6 & 23.0 \\
\hline & Water-L & 2.48 & 3.62 & 5.05 & 12.00 & 9.29 & 4.30 & 30.9 & 30.1 & 15.0 & 13.4 & 6.08 & 13.7 \\
\hline \multirow[t]{2}{*}{ Avicenna } & $\mathrm{W}$-watered & 7.41 & 11.84 & 26.54 & 26.11 & 22.51 & 8.05 & 21.3 & 18.7 & 4.43 & 9.36 & 10.9 & 16.2 \\
\hline & Water-L & 1.63 & 3.03 & 12.29 & 17.95 & 12.32 & 3.66 & 18.5 & 20.7 & 5.23 & 6.63 & 7.77 & 13.9 \\
\hline \multirow[t]{2}{*}{ Kashan } & W-watered & 7.55 & 8.79 & 21.04 & 17.62 & 17.67 & 8.66 & 17.4 & 19.3 & 10.9 & 15.6 & 13.4 & 18.5 \\
\hline & Water-L & 1.57 & 3.47 & 17.75 & 11.82 & 11.78 & 4.06 & 34.1 & 19.9 & 6.20 & 14.5 & 5.33 & 12.6 \\
\hline \multirow[t]{2}{*}{ Mashhad } & $\mathrm{W}$-watered & 8.86 & 9.05 & 13.80 & 19.23 & 17.13 & 7.91 & 11.8 & 18.8 & 8.70 & 13.6 & 7.05 & 14.3 \\
\hline & Water-L & 2.64 & 3.87 & 11.42 & 12.04 & 15.13 & 2.37 & 17.5 & 20.4 & 6.25 & 8.40 & 5.34 & 7.32 \\
\hline \multirow{2}{*}{ Isfahan } & $\mathrm{W}$-watered & 7.25 & 9.34 & 11.24 & 20.60 & 22.68 & 8.36 & 21.3 & 23.0 & 15.4 & 9.02 & 14.6 & 21.5 \\
\hline & Water-L & 1.56 & 3.13 & 9.23 & 14.97 & 17.06 & 2.14 & 32.1 & 22.1 & 10.1 & 5.37 & 5.01 & 13.1 \\
\hline \multirow[t]{2}{*}{ Bushehr } & W-watered & 6.70 & 11.88 & 20.82 & 17.10 & 25.91 & 11.18 & 18.3 & 16.3 & 5.54 & 7.47 & 7.39 & 9.17 \\
\hline & Water-L & 2.19 & 3.16 & 7.37 & 13.77 & 12.79 & 5.69 & 18.7 & 22.6 & 10.0 & 7.47 & 6.04 & 9.01 \\
\hline \multirow[t]{2}{*}{ Tukey's HSD ${ }_{5 \%}$} & & 1.30 & & & & & & 1.78 & & & & & \\
\hline & & \multicolumn{6}{|c|}{ Essential oil concentration (\%) } & \multicolumn{6}{|c|}{ Essential oil yield $\left(\mathrm{kg} \mathrm{ha}^{-1}\right)$} \\
\hline Urmia & $\mathrm{W}$-watered & 1.69 & 2.44 & 1.94 & 2.61 & 3.92 & 3.30 & 22.7 & 45.1 & 23.2 & 45.0 & 62.5 & 48.7 \\
\hline & Water-L & 1.99 & 2.79 & 2.16 & 4.41 & 5.56 & 3.45 & 9.10 & 18.8 & 23.4 & 51.3 & 49.2 & 9.30 \\
\hline Hamadan & W-watered & 1.95 & 2.05 & 2.01 & 2.38 & 1.82 & 2.85 & 22.7 & 33.0 & 29.7 & 25.3 & 28.4 & 34.8 \\
\hline & Water-L & 1.79 & 1.81 & 2.03 & 2.88 & 3.95 & 3.92 & 5.20 & 7.90 & 13.3 & 18.3 & 24.0 & 6.00 \\
\hline Kerman & $\mathrm{W}$-watered & 1.71 & 1.93 & 1.80 & 2.87 & 2.54 & 2.85 & 9.10 & 14.6 & 14.8 & 63.7 & 40.0 & 43.3 \\
\hline & Water-L & 1.93 & 2.31 & 2.24 & 2.70 & 3.37 & 3.57 & 6.50 & 11.4 & 13.5 & 37.7 & 30.2 & 8.50 \\
\hline Shiraz & $\mathrm{W}$-watered & 1.75 & 2.29 & 1.79 & 2.58 & 2.26 & 3.47 & 25.5 & 43.0 & 14.6 & 48.7 & 40.9 & 45.7 \\
\hline & Water-L & 2.07 & 2.63 & 2.51 & 2.34 & 3.33 & 4.83 & 15.7 & 27.4 & 18.0 & 28.3 & 29.8 & 34.4 \\
\hline Birjand & W-watered & 1.85 & 1.96 & 1.91 & 3.24 & 3.27 & 2.98 & 20.9 & 31.9 & 38.4 & 72.8 & 62.7 & 40.3 \\
\hline & Water-L & 1.77 & 1.92 & 1.92 & 3.24 & 4.12 & 3.75 & 5.70 & 8.80 & 11.1 & 29.0 & 32.4 & 18.8 \\
\hline Yazd & W-watered & 1.82 & 2.36 & 2.24 & 3.30 & 2.56 & 2.90 & 20.0 & 33.2 & 55.5 & 67.0 & 55.4 & 48.8 \\
\hline & Water-L & 1.95 & 2.51 & 2.37 & 2.80 & 4.55 & 3.58 & 14.6 & 27.1 & 17.8 & 46.0 & 24.6 & 22.0 \\
\hline Avicenna & $\mathrm{W}$-watered & 1.92 & 2.55 & 2.18 & 3.06 & 2.97 & 2.93 & 29.7 & 55.7 & 25.7 & 73.3 & 72.7 & 38.1 \\
\hline & Water-L & 1.77 & 2.13 & 2.08 & 3.25 & 3.52 & 3.92 & 5.30 & 13.2 & 13.4 & 36.3 & 31.6 & 19.5 \\
\hline Kashan & W-watered & 1.68 & 1.99 & 2.06 & 3.58 & 2.85 & 3.65 & 21.8 & 33.2 & 47.3 & 94.7 & 66.7 & 58.5 \\
\hline & Water-L & 1.82 & 2.01 & 2.06 & 3.05 & 4.25 & 4.23 & 9.60 & 13.8 & 22.3 & 54.0 & 26.6 & 20.7 \\
\hline Mashhad & $\mathrm{W}$-watered & 1.97 & 2.11 & 2.07 & 3.67 & 2.95 & 3.22 & 20.3 & 35.2 & 24.9 & 91.3 & 35.5 & 33.3 \\
\hline & Water-L & 2.31 & 2.31 & 2.39 & 2.71 & 3.42 & 3.53 & 10.5 & 18.0 & 17.1 & 29.3 & 27.4 & 6.20 \\
\hline Isfahan & $\mathrm{W}$-watered & 1.89 & 1.98 & 1.96 & 2.87 & 2.46 & 3.02 & 28.7 & 41.7 & 33.7 & 54.0 & 81.6 & 53.2 \\
\hline & Water-L & 2.01 & 2.38 & 2.25 & 2.84 & 3.55 & 3.82 & 9.90 & 16.3 & 20.9 & 21.7 & 30.8 & 10.6 \\
\hline Bushehr & W-watered & 1.82 & 1.93 & 1.94 & 3.10 & 2.56 & 3.18 & 22.0 & 36.8 & 22.3 & 35.7 & 47.6 & 32.7 \\
\hline & Water-L & 1.87 & 1.96 & 1.93 & 2.80 & 4.03 & 3.97 & 7.60 & 13.9 & 14.1 & 24.7 & 30.6 & 19.1 \\
\hline Tukey’s HSD $5 \%$ & & 0.17 & & & & & & 4.5 & & & & & \\
\hline
\end{tabular}

$W$-watered, well-watered; Water-L, water-limited. For each trait means with differences greater than Tukey's HSD value are not significantly different at 0.05 level

watered plants but that of the well-watered plants was observed in the 4th year of harvest (Table 2). Even though essential oil concentration of the majority of the examined fennel genotypes increased under the water-limited condition in most harvest years, essential oil yield of all examined genotypes (with the exception of genotype Urmia at the 4th year) decreased due to water limitation across all years. Consistent with seeds/plant and seed yield, most of the fennel genotypes produced the greatest essential oil yield in the 4th and 5th years of harvest for both well-watered and water-limited conditions (Table 2). Well-watered plants of genotypes Kashan and Isfahan numbered out the well-watered plants of other genotypes, though inadequately watered plants of Urmia, Shiraz, Kashan, and Yazd out-numbered the inadequately watered plants of remaining genotypes in terms of essential oil yield in most of the years of harvest.

Variation in fennel seed's essential oil concentration over the 6-year field study period and among the examined genotypes and irrigation regimes (e.g., 1.69 to $5.56 \%$ in Table 2) did not come as a surprise, as decreases in essential oil content 
with increase in the degree of fennel seed's maturation have been established; it may vary considerably with ecological and environmental conditions under which the plants have been grown and the seeds have matured (Telci et al. 2009). Essential oil production is not independent from the physiology of the whole plant, i.e., it depends on the metabolic state and background conditions under which the synthesizing tissue has undergone developmental program (Sangwan et al. 2001). This trait may vary with ontogeny, seasonal, and climatic variations (e.g., soil moisture, salinity, and prevalent temperature), mineral nutrition status, light quantity and quality, and duration. Being located in the center of the arid zone of Central Iran, total annual precipitation (starting from October and ending in September) over the course of the study period ranged from nearly $47 \mathrm{~mm}$ in 2017 to $217 \mathrm{~mm}$ in 2012 and the precipitations were mainly concentrated in late autumn to mid spring, but the pattern of its monthly and seasonal distribution varied considerably from year to year (Fig. 2). Mean monthly temperatures experienced varied from around $3-8{ }^{\circ} \mathrm{C}$ (in January) to $31-33{ }^{\circ} \mathrm{C}$ (in June and July), but some extreme temperatures were recorded over the 6-year study period. The latter variations in seasonal and monthly temperatures and precipitations may have affected the essential oil synthesis process and hence its concentration in different years. Moreover, the presumption of suitability of genotypes Yazd, Shiraz, and Kashan for a more profitable fennel seed production (compared with the remaining of the examined genotypes) is further substantiated as the greatest essential oil yields were also found for the genotypes Yazd, Kashan, Isfahan, Mashhad, and Birjand in some harvest years.

\subsection{Osmolytes and water relation attributes}

Analysis of variances of the traits related to osmoticums and water relations of the plants in the 6th year of harvest indicated that all attributes (i.e., leaf proline and TSC concentrations, RWC, and water potential) were significantly affected by the irrigation regimes and genotypes (Table 1). Furthermore, leaf proline concentration and water potential were significantly affected by the genotype $\times$ irrigation interaction. Mean TSC was increased by $17 \%$ and mean RWC was decreased by $19 \%$ when fennel plants were inadequately watered in the 6th year of harvest (data not shown). Furthermore, the greatest means of the aforementioned attributes, particularly under waterlimited conditions, were recorded for a set of genotypes characterized by greater seed yields in the presence of water limitation (e.g., Kashan, Yazd, Isfahan, and Shiraz). Leaf proline concentrations were increased (Fig. 3e) and water potentials (Fig. 3f) were decreased for all genotypes (albeit in different extents) when grown under water-limited conditions, compared with the well-watered conditions.

Stress-triggered proline accumulation could be due to its de novo synthesis, lowered degradation, and depressed utilization, or enhanced hydrolysis of proteins (Kaur and Asthir 2015). During osmotic stress episodes, the proline degradation pathway is downregulated, bringing about free proline accumulation. It has been established that proline catabolism is blocked in the root tips of sensitive genotypes under severely stressed conditions (Kavi Kishor and Sreenivasulu 2014). Upon the relief of the stress, however, growth is enhanced through reliance on the proline reservoir. The osmoprotecting role of the proline is associated with maintaining the leaf water status, as exemplified by maintained leaf water potential (Fig. 3f) and RWC (data not shown) for the examined fennel genotypes in the present study. Fennel genotypes with high proline and TSC accumulation capabilities (i.e., Yazd, Kashan, Shiraz, and Isfahan) were among those with the greatest RWC and leaf water potential, a finding that has been almost confirmed in previous studies (Gholami Zali and Ehsanzadeh 2018). Genotypic and species differences in the degrees and types of solutes accumulated, and thus osmotic adjustment capacities have been recognized in many plant species (Zhang et al. 1999; Kumar et al. 2017). The water deficiencyinduced increases in proline and TSC concentrations (74\% and $17 \%$, respectively) in fennel plants may have been brought about by enhanced biosynthesis, depressed degradation, or altered inter- and intra-cellular transport of these osmolytes. Our results are in line with those of Kumar et al. (2017), in that they found soluble sugars as major contributors to oleander (Nerium oleander L.) resistance to both drought and salt stresses. Patterns of RWC and water potential modifications in fennel genotypes in response to irrigation water availability bore an intimate resemblance, which is in accord with the resemblance of these attributes reported by Fernandes-Silva et al. (2016) in their work on drought-stricken olives. Moreover, proline is a multifunctional molecule that is able to prevent cellular damage by acting both as an osmotic agent and a radical (i.e., ROS) scavenger (Gholami Zali and Ehsanzadeh 2018). It must be emphasized that proline is not alone in tackling ROS-induced oxidative stresses. As it is discussed hereinafter, ROS abundance is often controlled by an associated increase in non-enzymatic and enzymatic antioxidants. Our data indicated that TSC- and proline-mediated osmotic adjustment has played a major role in productivity maintenance under water-limited conditions and supported the idea that osmotic adjustment sustains crop yield under drought stress (Blum 2017). We did not undertake direct osmotic adjustment measurements, but we may surmise that these genotypes differed in osmotic adjustment capability, based on the notable differences in RWC and water potential (Fig. 3f) sustainment along with TSC and proline accumulation (Fig. 3e) of the examined fennel genotypes. Furthermore, based on the proportionality between the osmolytes accumulation, RWC, water potential, and seed and DM sustainment, it may be inferred that certain genotypes (i.e., Yazd, Kashan, Shiraz, and Isfahan) outperformed the remaining genotypes not only in terms of undergoing osmotic adjustment but also with respect to seed yield under water-limited conditions. Generally, it is not 

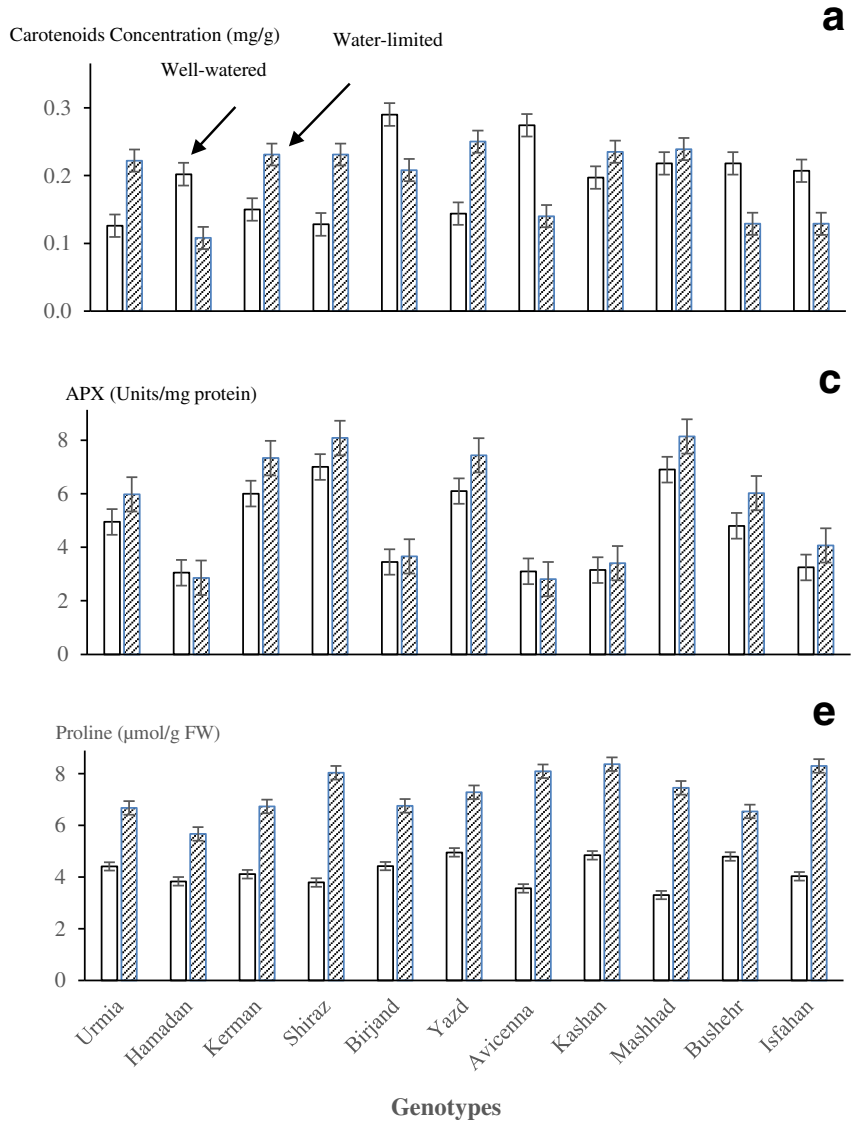

Fig. 3 Means of genotype $\times$ irrigation regime interactions for carotenoids concentration (a), catalase (CAT) (b), ascorbate peroxidase (APX) (c), superoxide dismutase (SOD) activities (d), proline concentration (e), and water potential of fennel (f). Carotenoids concentration, CAT, APX,

straightforward to find a singular plant trait responsible for the yield advantage of a crop under water-limited condition. The presented data herein, however, depicts the less-studied fennel as a crop that resembles well-attended crops such as barley, wheat, maize, sorghum, chickpea, pea, pigeon pea, soybean, canola, mustard, castor bean, and sunflower (Blum 2017) in that a positive and clear association exists between osmotic adjustment and yield under water-limited conditions. These osmotic adjustment measures have, presumably, helped the inadequately watered fennel plants to sustain the photosynthetic activity and provide photoassimilates to lessen flower infertility and, consequently, maintain seeds/plant and seed yield.

\subsection{Antioxidative activities}

Statistical analyses of the antioxidative activities revealed that carotenoids concentration and CAT, SOD, and APX activities were significantly affected by irrigation regime, genotype, and genotype $\times$ irrigation interaction (Table 1 ). Carotenoids concentration responded to irrigation regime in a genotype-specific manner, i.e., while it increased with water limitation for half of the genotypes, it decreased under water-limited condition in the
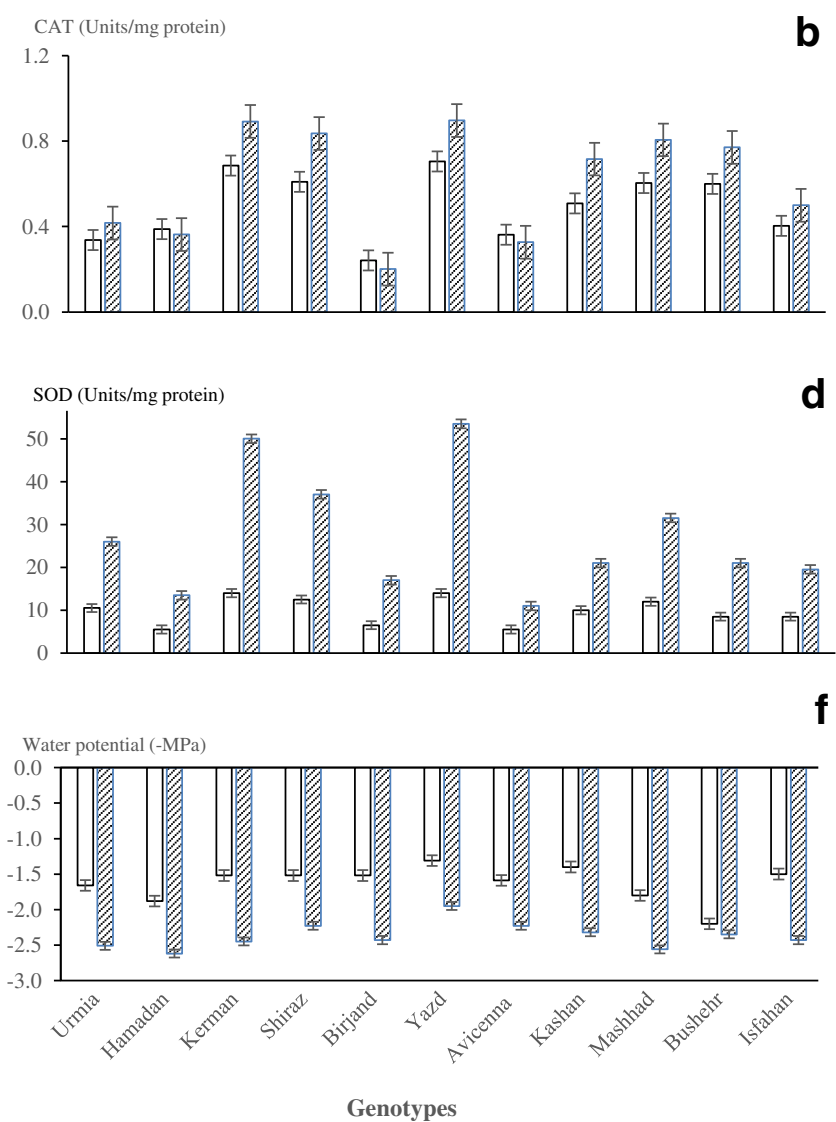

and SOD activities are means of data obtained from measurements in 2011 and 2012. Proline concentration and water potential have been measured on plant leaves in 2017. Bars are indicative of standard error

other half, in comparison with the well-watered condition (Fig. 3a). CAT (Fig. 3b) and APX (Fig. 3c) activities responded to water limitation in genotype-specific manners. In effect, while in certain genotypes, no notable changes were observed, in the remaining genotypes, significant increases in the activities of the latter enzymes were observed when plants were grown under water-limited conditions. SOD activities were increased substantially (these increases varied from $100 \%$ to $283 \%$ among the genotypes) for all examined genotypes in response to water limitation (Fig. 3d). The greatest activities of this set of three enzymes in the inadequately watered plants were found in the genotypes Yazd, Kerman, and Shiraz and the greatest means for carotenoids concentrations were detected in the genotypes Yazd, Mashhad, and Bushehr.

Almost all plant species withstand drought stress through relying on a myriad of mechanisms, but the extent of tolerance and the mechanism relied on vary from species to species. A wide range of stresses, including drought, trigger a plethora of antioxidative systems to circumvent the potentially harmful effects caused by stress-induced generation of ROS (Reddy et al. 2004). Stomatal limitation aside, drought induces decreases in photosynthesis through metabolic impairments, due to an 
imbalance between light capture and its utilization in photosystem II (PSII), often leading to a boost in the ROS generation. The latter phenomenon per se necessitates triggering antioxidative machinery. While SOD, CAT, and APX can be categorized into the enzymatic type, carotenoids are among the non-enzymatic types of the antioxidative system. All of the aforementioned antioxidative defense components were more or less enhanced when fennel plants were exposed to water limitation (Fig. 3a-d). However, the magnitude of the increase in the activities of antioxidant enzymes and the amount of antioxidants are extremely variable among species, genotypes of the same species, different development stages and physiological states of the same plant, and more importantly with duration and intensity of the stress (Reddy et al. 2004). Therefore, a certain variation in the level of expression of these antioxidants in the fennel genotypes did not come as a surprise. A higher antioxidant capacity and, hence, tolerance to drought is often associated with increases in the expression and activity of CAT, SOD, and APX (Zandalinas et al. 2018). Moreover, drought-high light stress tolerance of the aridity-adapted cashew (Anacardium occidentale) plants has been featured by enhancements in the activities of SOD and APX (Lima et al. 2018), which confirms our findings. Hence, correlative associations between the activity of these enzymes and seed yield and DM sustainment in the presence of stress are established. Evidence for such associations was obtained in the present study, where genotypes that were capable of enhancing SOD, CAT, and APX activities (e.g., Yazd and Shiraz) and maintaining carotenoids concentration (e.g., Yazd, Bushehr, and Mashhad) were among the high-yielding ones, particularly under water-limited condition. Based on the notable accumulation of osmolytes and upregulation of antioxidative enzymes, it may be concluded that key to the partially maintained yields of inadequately watered plants of certain fennel genotypes (e.g., Yazd, Shiraz, and Kashan) lies in their osmotic adjustment capability accompanied by an efficient antioxidative defensive capacity. Maintaining leaf water and antioxidative defense has, perhaps, enabled inadequately watered Yazd, Shiraz, and Kashan plants to sustain, at least in part, key physiological functions (e.g., photosynthesis) and thereby seed and DM.

The present long-term continuous yield study enabled us to make an accurate assessment of the response of perennial fennel response to water-limited conditions. Owing to its natural habitat, this herbaceous medicinal species has evolved key osmoregulatory and antioxidative defense measures, making some of the fennel genotypes at least partially resilient to water limitation. The smallest water deficiency-induced reductions (ranging from 20 to $35 \%$ ) in the seed yield of the 5th year were found in the genotypes Yazd, Bushehr, Urmia, Kashan, and Shiraz. The least water deficiency-associated reductions for the 6th year (ranging from 46 to 69\%) were observed in Shiraz, Bushehr, Yazd, Avicenna, and Kashan. Interestingly, the greatest amount of the key osmoregulatory substance (i.e., proline) was detected in the inadequately watered plants (measured only in the 6th year) of the genotypes Kashan, Isfahan, Shiraz, Avicenna, and Yazd. Hence, in contrary to a view arguing that osmotic adjustment mainly serves plant survival rather than productivity, fennel typifies a plant species encompassing certain genotypes with osmoregulatory measures beneficial to seed and dry mass production in water-limited circumstances. The presented data indicates for the first time that ratooning of fennel may lend us a hand in safeguarding sustainability and producing natural products with a high degree of environmental compatibility and additional economic advantage. Alike a majority of other perennial species (Angelinia et al. 2009), not only ratooned fennel needs limited soil management practices, it also may be produced with minimal pesticide use, due to having few natural pests. These features bring about ecological advantages for ratooned fennel in comparison with conventional annual crop species.

\section{Conclusions}

Diversifying farming systems, sustaining biodiversity, and minimizing chemical and machinery inputs are especially crucial in areas where crop production practices have been extended into marginal conditions. Our interest in the potential role of fennel as a ratooned (and hence perennial) species had arisen from the suitability of such species for organic and sustainable production systems. Novelty of the present study lies in the finding that ratooning fennel may lead to the production of an acceptable seed and essential oil yield over a 6-year production cycle with minimum energy, labor, chemicals, and monetary inputs along with abating cultural practices. Based on the 6-year data gathered and osmoregulatory and antioxidative defense capabilities found, it can be concluded that certain fennel genotypes have the competence to maintain, at least in part, seeds/plant and hence seed yield and DM and seem reasonably suited for cultivation as a ratoon crop in erosion-threatened soils and drought-prone climatic conditions typically encountered in the Middle East countries such as Iran. Such novel findings are particularly valuable if put into action in arid and semi-arid regions anticipated to experience further environmental hardships due to the current climate change.

\section{Compliance with ethical standards}

Conflict of interest The authors declare that they have no conflict of interest.

\section{References}

Angelinia LG, Ceccarinia L, Nassi o Di Nasso N, Bonari E (2009) Comparison of Arundo donax L. and Miscanthus x giganteus in a long-term field experiment in Central Italy: analysis of productive characteristics and energy balance. Biomass Bioenergy 33:635-643. https://doi.org/10.1016/j.biombioe.2008.10.005 
Arundale RA, Dohleman FG, Heaton EA, Mcgrath JM, Voigt TB, Long SP (2014) Yields of Miscanthus $\times$ giganteus and Panicum virgatum decline with stand age in the Midwestern USA. GCB Bioenergy 6: 1-13. https://doi.org/10.1111/gcbb.12077

Ashraf M, Foolad MR (2007) Roles of glycine betaine and proline in improving plant abiotic stress resistance. Env Exp Bot 59:206216. https://doi.org/10.1016/j.envexpbot.2005.12.006

Askari E, Ehsanzadeh P (2015) Drought stress mitigation by foliar application of salicylic acid and their interactive effects on physiological characteristics of fennel (Foeniculum vulgare Mill.) genotypes. Acta Physiol Plant 37:4. https://doi.org/10.1007/s11738-014-1762-y

Assefa T, Wu J, Beebe SE, Rao IM, Marcomin D, Claude RJ (2015) Improving adaptation to drought stress in small red common bean: phenotypic differences and predicted genotypic effects on grain yield, yield components and harvest index. Euphytica 203:477489. https://doi.org/10.1007/s10681-014-1242-x

Azizi A, Yan F, Honermeier B (2009) Herbage yield, essential oil content and composition of three oregano (Origanum vulgare L.) populations as affected by soil moisture regimes and nitrogen supply. Indust Crop Prod 29:554-561. https://doi.org/10.1016/j.indcrop.2008.11.001

Bettaieb I, Zakhama N, Aidi Wannes W, Kchouk ME, Marzouk B (2009) Water deficit effects on Salvia officinalis fatty acids and essential oils composition. Sci Hortic 120:271-275. https://doi.org/10.1016/j. scienta.2008.10.016

Blum A (2017) Osmotic adjustment is a prime drought stress adaptive engine in support of plant production. Plant Cell Environ 40:4-10. https://doi.org/10.1111/pce.12800

Carrubba A, Catalano C (2009) Essential oil crops for sustainable agriculture - a review. In: Lichtfouse E (ed) Climate change, intercropping, pest control and beneficial microorganisms. Sustainable agriculture reviews, Vol 2, Springer, Dordrecht. https:// doi.org/10.1007/978-90-481-2716-0 8

Carrubba A, Militello M (2013) Nonchemical weeding of medicinal and aromatic plants. Agron Sustain Dev 33:551-561. https://doi.org/10. 1007/s13593-012-0122-9

Carrubba A, la Torre R, Saiano F, Aiello P (2008) Sustainable production of fennel and dill by intercropping. Agron Sustain Dev 28:247-256. https://doi.org/10.1051/agro:2007040

Diao W-R, Hu Q-P, Zhang H, Xu J-G (2014) Chemical composition, antibacterial activity and mechanism of action of essential oil from seeds of fennel (Foeniculum vulgare Mill.). Food Control 35:109 116. https://doi.org/10.1016/j.foodcont.2013.06.056

Echarte L, Andrade FH (2003) Harvest index stability of Argentina maize hybrids released between 1965 and 1993. Field Crop Res 82:1-12. https://doi.org/10.1016/S0378-4290(02)00232-0

Fernandes-Silva AA, López-Bernal A, Ferreira TC, Villalobos FJ (2016) Leaf water relations and gas exchange response to water deficit of olive (cv. Cobrançosa) in field grown conditions in Portugal. Plant Soil 402:191-209. https://doi.org/10.1007/s11104-015-2786-9

Gholami Zali A, Ehsanzadeh P (2018) Exogenous proline improves osmoregulation, physiological functions, essential oil, and seed yield of fennel. Ag Water Manage 197:138-146. https://doi.org/10.1016/ j.agwat.2017.11.023

Ingvordsen $\mathrm{CH}$, Backes $\mathrm{G}$, Lyngkjær MF, Peltonen-Sainio P, Jensen JD, Jalli M, Jahoor A, Rasmussen M, Mikkelsen TN, Stockmarr A, Jørgensen RB (2015) Significant decrease in yield under future climate conditions: stability and production of 138 spring barley accessions. Eur J Agron 63:105-113. https://doi.org/10.1016/j.eja. 2014.12.003

Kaur G, Asthir B (2015) Proline: a key player in plant abiotic stress tolerance. Biol Plant 59:609-619. https://doi.org/10.1007/s10535015-0549-3

Kavi Kishor PB, Sreenivasulu N (2014) Is proline accumulation per se correlated with stress tolerance or is proline homeostasis a more critical issue? Plant Cell Environ 37:300-311. https://doi.org/10. 1111 pce. 12157

Kumar D, Al Hassan M, Naranjo MA, Agrawal V, Boscaiu M, Vicente O (2017) Effects of salinity and drought on growth, ionic relations, compatible solutes and activation of antioxidant systems in oleander (Nerium oleander L.). PLoS One 12(9):e0185017. https://doi.org/ 10.1371/journal.pone. 0185017

Laribi B, Bettaieb I, Kouki K, Sahli A, Mougou A, Marzouk B (2009) Water deficit effects on caraway (Carum carvi L.) growth, essential oil and fatty acid composition. Indust Crop Prod 30:372-379. https://doi.org/10.1016/j.indcrop.2009.07.005

Lima CS, Ferreira-Silva SL, Carvalho FEL, Neto MCL, Aragão RM, Silva EN, Sousa RMJ, Silveira JAG (2018) Antioxidant protection and PSII regulation mitigate photo-oxidative stress induced by drought followed by high light in cashew plants. Env Exp Bot 149:59-69. https://doi.org/10.1016/j.envexpbot.2018.02.001

LiXin Z, ShengXiu L, ZongSuo L (2009) Differential plant growth and osmotic effects of two maize (Zea mays L.) cultivars to exogenous glycinebetaine application under drought stress. Plant Growth Regul 58:297-305. https://doi.org/10.1007/s10725-009-9379-7

Özel A, Kosar I, Demirbilek T, Erden K (2019) The changes in yields and volatile oil composition of fennel (Foeniculum vulgare Mill.) in high plant populations. Ital J Agron 14:147-152. https://doi.org/10.4081/ija. 2019.1347

Reddy AR, Chaitanya KV, Vivekanandan M (2004) Drought-induced responses of photosynthesis and antioxidant metabolism in higher plants. J Plant Physiol 161:1189-1202. https://doi.org/10.1016/j. jplph.2004.01.013

Rogé P, Snapp S, Kakwera MN, Mungai L, Jambo I, Peter B (2016) Ratooning and perennial staple crops in Malawi. A review. Agron Sustain Dev 36:50-18. https://doi.org/10.1007/s13593-016-0384-8

Sangwan NS, Farooqi AHA, Shabih F, Sangwan RS (2001) Regulation of essential oil production in plants. Plant Growth Regul 34:3-21. https://doi.org/10.1023/A:1013386921596

Stankovic MS, Petrovic M, Godjevac D, Stevanovic ZD (2015) Screening inland halophytes from the central Balkan for their antioxidant activity in relation to total phenolic compounds and flavonoids: are there any prospective medicinal plants? J Arid Environ 120:26-32. https://doi.org/10.1016/j.jaridenv.2015.04.008

Telci I, Demirtas I, Sahin A (2009) Variation in plant properties and essential oil composition of sweet fennel (Foeniculum vulgare Mill.) fruits during stages of maturity. Indust Crop Prod 30:126130. https://doi.org/10.1016/j.indcrop.2009.02.010

van Andel TR, Croft S, van Loon EE, Quiroz D, Towns AM, Raes N (2015) Prioritizing West African medicinal plants for conservation and sustainable extraction studies based on market surveys and species distribution models. Biol Conserv 181:173-181. https://doi.org/ 10.1016/j.biocon.2014.11.015

Würschum T, Leiser WL, Langer SM, Tucker MR, Longin CFH (2018) Phenotypic and genetic analysis of spike and kernel characteristics in wheat reveals long-term genetic trends of grain yield components. Theor Appl Gen 131: 2071-2084.

Zandalinas SI, Mittler R, Balfagón D, Arbona V, Gómez-Cadenas A (2018) Plant adaptations to the combination of drought and high temperatures. Physiol Plant 162:2-12. https://doi.org/10.1111/ppl.12540

Zhang J, Nguyen HT, Blum A (1999) Genetic analysis of osmotic adjustment in crop plants. J Exp Bot 50:291-302. https://doi.org/10.1093/ $\mathrm{jxb} / 50.332 .291$

Publisher's note Springer Nature remains neutral with regard to jurisdictional claims in published maps and institutional affiliations. 